\title{
Platinum(II) Complexes with Tetradentate Schiff Bases as Ligands: Synthesis, Characterization and Detection of DNA Interaction by Differential Pulse Voltammetry
}

\author{
LIJUN LI ${ }^{*}$, CHAO TIAN, CHENG WANG, \\ GUANGYUAN WANG, LIANZENG WANG and JIANLONG DU \\ College of Chemistry \& Environmental Science \\ Chemical Biology Key Laboratory of Hebei Province \\ Hebei University, Baoding 071002, China
}

Received 12 July 2011; Accepted 20 September 2011

\begin{abstract}
Five sterically hindered platinum(II) complexes with tetradentate schiff bases as ligands, $[\mathrm{Pt}(\mathrm{L})]\left(\mathrm{L}=N, N^{\prime}\right.$-bisalicylidene-1,2-ethylenediamine $\left(\mathrm{L}^{1}\right), N, N^{\prime}$-bisalicylidene-1,2-cyclohexanediamine $\left(\mathrm{L}^{2}\right), \mathrm{N}, \mathrm{N}$ '-bis(5-hydroxylsalicylidene)-1,2-cyclohexanediamine $\left(\mathrm{L}^{3}\right), N, N^{\prime}$-bisalicylidene-1,2-diphenylethylenediamine $\left(\mathrm{L}^{4}\right)$ and $N, N^{\prime}$-bis(3-tert-butyl-5-methyl-salicylidene)-1,2diphenylethylenediamine $\left(\mathrm{L}^{5}\right)$ ) have been synthesized and characterized by IR spectroscopy and elemental analysis. The sterical hindrance of antitumor drug candidates potentially makes them less susceptible to deactivation by sulphur containing proteins and helping to overcome resistance mechanisms. The interaction of these metal complexes with fish sperm single-stranded DNA (ssDNA) was studied electrochemically based on the oxidation signals of guanine and adenine. Differential pulse voltammetry was employed to monitor the DNA interaction in solution by using renewable pencil graphite electrode. The results indicate that ligands with different groups can strongly affect the interaction between $[\mathrm{Pt}(\mathrm{L})]$ complexes and ssDNA due to sterical hindrances and complex $\left[\mathrm{Pt}\left(\mathrm{L}^{1}\right)\right]$ has the best interaction with DNA among the five complexes.
\end{abstract}

Keywords: Platinum(II) complexes, Synthesis, DNA interaction, Differential pulse voltammetry.

\section{Introduction}

Schiff bases are used as substrates in the preparation of a lot of industrial compounds via ring closure, cycloaddition and replacement reactions ${ }^{1}$. Schiff bases are also important class of compounds in medicinal and pharmaceutical fields such as antimicrobial ${ }^{2,3}$, antifungal ${ }^{4,5}$ and antitumor activituy, ${ }^{6,7}$. The landmark discovery of cisplatin by Rosenberg in 1965 heralded a new era of anticancer drug research based on metallopharmaceuticals ${ }^{8}$. However, it has several limitations including toxicity (nephrotoxicity, neurotoxicity, ototoxicity and 
emetogenesis) and intrinsic or acquired resistance ${ }^{9}$, for instance, $\mathrm{Pt}(\mathrm{II})$ compounds have a strong thermodynamic preference for binding to sulfur donor ligands, hence, before antitumor platinum drugs reach DNA in the nucleus of tumor cells, they may interact with various compounds, including sulfur-containing molecules, these interactions are generally thought to play a primary mechanism underlying tumor resistance to platinum compounds, their inactivation and their side effects ${ }^{10}$. Specific chemical and structural features can be incorporated into new Pt compounds so that they are able to circumvent a specific drug resistance mechanism, such as sterically hindered Pt complexes ${ }^{11}$. There also have been efforts directed at the design of unconventional complexes that violate the original structureactivity relationships, such as trans Pt compounds ${ }^{12}$ and binuclear Pt complexes ${ }^{13}$. There has also been interest in Pt(IV) complexes ${ }^{14}$ for their potential as orally active agents. It is hoped that they will overcome Pt drug resistance in tumors and be applicable to a broader range of cancers.

In recent years, there has been a gradually attempt in the application of electrochemical techniques ${ }^{15,16}$ to understand interactions between DNA and moleculers due to cheapness, simplicity, fast detection and require small amount of sample with respect to the generally used spectroscopic methods ${ }^{17}$. Keeping the above knowledge in mind, the present paper involves preparing and characterizing five new tetradentate sterically hindered platinum(II) complexes with schiff bases as ligands which have more thermodynamic stabilities. In continuation of the study, special attention has been paid to the application of electrochemical measurements based on the interaction of these metal complexes with ssDNA via differential pulse voltammetry using disposable pencil graphite electrode.

\section{Experimental}

Reagent grade chemicals were used as received unless otherwise stated. Elemental analysis were determined on a Elemental Vario EL III elemental analyzer. The IR spectra were recorded using $\mathrm{KBr}$ pellets and a Perkin-Elmer Model-683 spectrophotometer. The ${ }^{1} \mathrm{H}$ NMR spectra were recorded on a Bruker AVIII 600 NMR spectrometer. Electrochemical experiments are carried on a PC driven PARC 273A potentiostat: galvanostat running with mode 270 electrochemical analysis software or on a CHI 660 workstation. A threecompartment cell contains a working electrode (pencil graphite), a counter electrode (Pt plane) and a calomel reference electrode.

Schiff bases ligands $\left(\mathrm{L}^{1} \sim \mathrm{L}^{5}\right)$ were synthesized according to a published procedure ${ }^{18}$. To a solution of the amine (1 equiv.) in ethanol was added the relevant aldehyde derivatives (1 equiv.). The resulting yellow/orange solution was refluxed for $1.5 \mathrm{~h}$. After cooling to room temperature the solution was concentrated in vacuo to yield a yellow solid product.

\section{Synthesis of $N, N^{\prime}$-bisalicylidene-1,2-ethylenediamine $\left(L^{1}\right)$}

Yellow solid product (406 mg, 91\%): mp 120-122 ${ }^{\circ} \mathrm{C}$. IR(KBr, pellet)v $/ \mathrm{cm}^{-1}: 1632,1578$, $1498,1283,1149,1042,1021,857,749,741 .{ }^{1} \mathrm{H}$ NMR $\left(600 \mathrm{M} \mathrm{Hz}, \mathrm{DMSO}-\mathrm{d}_{6}\right), \delta: 6.850-$ $7.438(\mathrm{~m}, 8 \mathrm{H}, \mathrm{Ar}-\mathrm{H}), 8.600(\mathrm{~s}, 2 \mathrm{H},-\mathrm{CH}=\mathrm{N}-), 13.380(\mathrm{~s}, 2 \mathrm{H},-\mathrm{OH}), 3.932\left(\mathrm{~s}, 4 \mathrm{H},-\mathrm{CH}_{2}-\right.$ $\mathrm{CH}_{2}$ ). Anal. Calc. for $\mathrm{C}_{16} \mathrm{H}_{16} \mathrm{~N}_{2} \mathrm{O}_{2}$ (268.31): C, 71.62; H, 6.01; N, 10.44. Found: C, 71.54; H, 6.13; N, 10.41 .

\section{Synthesis of $N, N^{\prime}$-bisalicylidene-1,2-cyclohexanediamine $\left(L^{2}\right)$}

Yellow solid product (195 mg, 93\%): mp 118-119 ${ }^{\circ} \mathrm{C}$. IR(KBr, pellet)v $/ \mathrm{cm}^{-1}: 1629,1579$, 1501, 1280, 1148, 1095, 1045, 767, 758. ${ }^{1} \mathrm{H}$ NMR (600M Hz, DMSO-d 6 ), $\delta: 13.325$ (s, $2 \mathrm{H}$, $-\mathrm{OH}), 8.490$ (s, $2 \mathrm{H},-\mathrm{CH}=\mathrm{N}-)$, 6.790-7.350 (m, $8 \mathrm{H}, \mathrm{Ar}-\mathrm{H}), 3.400-3.450$ (m, $2 \mathrm{H},-\mathrm{CH}-$ ), 
1.440-1.910 (m, $8 \mathrm{H},-\mathrm{CH}_{2}-\mathrm{CH}_{2}$-). Anal. Calc. for $\mathrm{C}_{20} \mathrm{H}_{22} \mathrm{~N}_{2} \mathrm{O}_{2}$ (322.40): C, 74.51; H, 6.88; N, 8.69. Found: C, 74.43; H, 6.75; N, 8.62.

\section{Synthesis of $N, N^{\prime}$-bis(5-hydroxyl-salicylidene)-1,2-cyclohexanediamine $\left(L^{3}\right)$}

To a $100 \mathrm{~mL}$ three-neck flask, equipped with a reflux condenser, thermometer, a nitrogen source and magnetic stirrer was added hydroquinone $(2.0 \mathrm{~g}, 0.018 \mathrm{~mol})$, sodium hydroxide $(4.0 \mathrm{~g}, 0.10 \mathrm{~mol})$, distilled water $40 \mathrm{~mL}$, and chloroform $8.0 \mathrm{~mL}(98 \mathrm{mmol})$. The mixture was heated to reflux for $8 \mathrm{~h}$. After cooling, the reaction mixture was acidified to PH 2 3 with $2 \mathrm{~N}$ hydrochloric acid, and extracted with ethyl acetate. The ethyl acetate extract was treated with vacuum distillation, dried and obtained crude 5-hydroxylsalicylaldehyde (1.7 g). The crude product was purified by column chromatography gave yellow solid product $\left(\mathrm{a}_{2}\right)$ (0.41 g, 32.6\%): mp: $94-97{ }^{\circ} \mathrm{C}$; IR(KBr, pellet)v $/ \mathrm{cm}^{-1}: 3441,1660,1631,1582,1486,1398$, $1278,1151,1039,943,881,801,769,641,484 .{ }^{1} \mathrm{H}$ NMR $\left(600 \mathrm{M} \mathrm{Hz}, \mathrm{DMSO}-\mathrm{d}_{6}\right), \delta: 6.812-$ 6.974(m, 3H, Ar-H), 10.199(s, 1H, -CHO).

Yellow solid product (159 mg, 90\%): mp 216-218 ${ }^{\circ} \mathrm{C}$. IR(KBr, pellet $) \mathrm{v} / \mathrm{cm}^{-1}: 3329$, $1641,1630,1483,1300,1157,1047,804,788 .{ }^{1} \mathrm{H}$ NMR $\left(600 \mathrm{M} \mathrm{Hz}\right.$, DMSO-d $\left.\mathrm{d}_{6}\right), \delta: 12.460$ (s, $2 \mathrm{H},-\mathrm{OH}), 8.365(\mathrm{~s}, 2 \mathrm{H},-\mathrm{CH}=\mathrm{N}-), 8.930(\mathrm{~s}, 2 \mathrm{H},-\mathrm{OH}), 6.662-6.728(\mathrm{~m}, 6 \mathrm{H}, \mathrm{Ar}-\mathrm{H})$, 1.430-1.880 (m, $8 \mathrm{H},-\mathrm{CH}_{2}-\mathrm{CH}_{2}$ ). Anal. Calc. for $\mathrm{C}_{20} \mathrm{H}_{22} \mathrm{~N}_{2} \mathrm{O}_{4}$ (354.40): C, 67.78; H, 6.26; N, 7.90. Found: C, 67.85; H, 6.13; N, 8.11.

\section{Synthesis of $N, N^{\prime}$-bisalicylidene-1,2-diphenylethylenediamine $\left(L^{4}\right)$}

Yellow solid product (195.1 mg, 93\%): m.p. 201 202 ${ }^{\circ} \mathrm{C}$; $\mathrm{IR}\left(\mathrm{KBr}\right.$, pellet)v/ $\mathrm{cm}^{-1}: 1623$, 1576, 1496, 1279, 1211, 1151,1052, 859,760. ${ }^{1} \mathrm{H}$ NMR (600M Hz, DMSO-d 6 ), $\delta:$ ppm: 5.0513 (s, 2H, Benzyl-H), 6.8181-6.8650 (m, 8 H, Ar-H), 7.1947-7.3197 (m, 10H, Ph-H), $8.4195(\mathrm{~s}, 1 \mathrm{H},-\mathrm{CH}=\mathrm{N}-), 8.4244(\mathrm{~s}, 1 \mathrm{H},-\mathrm{CH}=\mathrm{N}-), 13.1777(\mathrm{~s}, 2 \mathrm{H},-\mathrm{OH})$. Anal. Calc. for $\mathrm{C}_{28} \mathrm{H}_{24} \mathrm{~N}_{2} \mathrm{O}_{2}$ (420.18): C, 79.98; H, 5.75; N, 6.66. Found: C, 79.93; H, 5.86; N,6.47.

\section{Synthesis of N,N'-bis(3-tert-butyl-5-methyl-salicylidene)-1,2- diphenylethylenediamine $\left(L^{5}\right)$}

The reaction mixture with p-methylphenol $(10.8 \mathrm{~g}, 0.1 \mathrm{~mol})$ and tert-butyl alcohol $(8.9 \mathrm{~g}$, $0.12 \mathrm{~mol}$ ) was stirred on a $50{ }^{\circ} \mathrm{C}$ oil bath for 6.5 hour, then $50 \mathrm{~mL}$ water was added, the oil layer was separated, and the water layer was extracted with ether. The combined organic layer was washed with water, $\mathrm{Na}_{2} \mathrm{CO}_{3} / \mathrm{H}_{2} \mathrm{O}$ and $\mathrm{H}_{2} \mathrm{O}$. The products were separated by silica gel chromatography to give 2-t-butyl-2-methylphenol (10.3618 g, 71\%): ${ }^{1} \mathrm{H}$ NMR $(600 \mathrm{M}$ Hz, DMSO-d 6 ), $\delta$ : ppm: 1.3981 (s, 9 H, t-Bu-H), 2.2699 (s, 3 H, Me-H), 4.2456 (br, $1 \mathrm{H},-$ $\mathrm{OH}), 6.5568$ (d, 1H, Ar-H), $6.8696(\mathrm{~d}, 1 \mathrm{H}, \mathrm{Ar}-H), 7.0654$ (s, $1 \mathrm{H}, \mathrm{Ar}-H)$.

To a $50 \mathrm{~mL}$ three-neck flask, equipped with a reflux condenser, thermometer, a nitrogen source and magnetic stirrer was added anhydrous toluene $4 \mathrm{~mL}, 2$-tert-butylcresol $(1.6456 \mathrm{~g}$, $10 \mathrm{mmol}$ ), tin(IV) tetrachloride $0.6003 \mathrm{~g}$ and 2,6 -lutidine $0.547 \mathrm{~g}$. The reaction was exothermic. The mixture was stirred for $20 \mathrm{~min}$ at room temperature, then paraformaldehyde (0.66 g, $22 \mathrm{mmol})$ was added. The mixture was heated to about $100{ }^{\circ} \mathrm{C}$ for $5 \mathrm{~h}$. After cooling, the reaction mixture was poured into water, acidified to $\mathrm{pH} 2 \sim 3$ with $2 \mathrm{~N}$ hydrochloric acid and extracted with ether. The ether extract was washed with a saturated sodium chloride solution, dried $\left(\mathrm{Na}_{2} \mathrm{SO}_{4}\right)$ and concentrated to leave crude 3-t-butyl-5methylsalicylaldehyde. Purification by column chromatography (ethyl acetate/petroleum ether) gave the light yellow solid product $\left(\mathrm{a}_{1}\right)(1.1535 \mathrm{~g}, 60 \%)$ : mp 67-69 ${ }^{\circ} \mathrm{C}$. ${ }^{1} \mathrm{H}$ NMR (600M Hz, DMSO-d 6 ), $\delta$ : ppm: 1.4109 (s, 9 H, t-Bu-H), 2.3240 (s, $3 \mathrm{H}, \mathrm{Me}-H), 7.1781$ (d, 1 H, Ar-H), 7.3308 (d, 1 H, Ar-H), 9.8246 (s, 1 H, -CHO), 11.6025 (s, 1 H, -OH).

Yellow solid product (122.9 mg, 88\%): m.p. $179-181{ }^{\circ} \mathrm{C}$; IR(KBr, pellet)v/ $\mathrm{cm}^{-1}: 2957$, $1625,1601,1440,1263,1165,1047,862,788 .{ }^{1} \mathrm{H}$ NMR (600M Hz, DMSO-d 6 ), $\delta:$ ppm: 
1.4252 (s, $18 \mathrm{H}, \mathrm{t}-\mathrm{Bu}), 2.2170\left(\mathrm{~s}, 6 \mathrm{H},-\mathrm{CH}_{3}\right), 4.8339$ (s, $2 \mathrm{H}$, Benzyl-H), 6.7873 (d, 2H, 2-Ar-H), 7.1183 (d, 2H, 4-Ar-H), 7.2187-7.3744 (m, 10H, Ph-H), 8.0995 (s, 2H, -CH=N-), 12.3400 (br, 2H, -OH). Anal. Calc. for $\mathrm{C}_{38} \mathrm{H}_{44} \mathrm{~N}_{2} \mathrm{O}_{2}$ (560.34): C, 81.39; H, 7.91; N, 5.00. Found: C, 81.25; H, 7.83; N,4.82.

Synthesis of $\left[\operatorname{Pt}\left(L^{1}\right)\right]$

$\mathrm{K}_{2} \mathrm{PtCl}_{4}(15 \mathrm{mg}, 0.036 \mathrm{mmol})$ was dissoved in $1 \mathrm{~mL}$ distilled water, then $\mathrm{L}^{1}$ (9 mg, $\left.0.034 \mathrm{mmol}\right)$ dissolving in absolute methanol was added. The reaction mixture was stired in room temperature for $72 \mathrm{~h}$. The complex $\left[\mathrm{Pt}\left(\mathrm{L}^{1}\right)\right]$ was purificated by column chromatography (ethanol/petroleum ether) gave the yellow solid product $\left(12 \mathrm{mg}, 77.5 \%\right.$ ):m.p. $>300{ }^{\circ} \mathrm{C}$; $\mathrm{IR}\left(\mathrm{KBr}\right.$, pellet) $\mathrm{v} / \mathrm{cm}^{-1}: 1625,1129,563,485$. Anal. Calc. for $\mathrm{C}_{16} \mathrm{H}_{14} \mathrm{C}_{2} \mathrm{O}_{2} \mathrm{Pt}$ (461.37): $\mathrm{C}$, 41.65; H, 3.06; N, 6.07. Found: C, 40.97; H, 2.59; N, 6.41.

\section{Synthesis of $\left[\operatorname{Pt}\left(L^{2}\right)\right]$}

The synthesis of $\left[\mathrm{Pt}\left(\mathrm{L}^{2}\right)\right]$ was carried out in an identical manner to $\left[\mathrm{Pt}\left(\mathrm{L}^{1}\right)\right]$ starting from $\mathrm{K}_{2} \mathrm{PtCl}_{4}(15 \mathrm{mg}, 0.036 \mathrm{mmol})$ and $\mathrm{L}^{2}(12 \mathrm{mg}, 0.037 \mathrm{mmol})$. Yellow solid (13 mg, 70.12\%). $\mathrm{IR}\left(\mathrm{KBr}\right.$, pellet)v/cm $\mathrm{cm}^{-1}: 1620,1124,566,468$. Anal. Calc. for $\mathrm{C}_{23} \mathrm{H}_{21} \mathrm{~N}_{2} \mathrm{O}_{2} \mathrm{Pt}$ (530.50): $\mathrm{C}$, 47.54; H, 4.37; N, 5.28. Found: C, 47.35; H, 4.31; N, 5.19.

\section{Synthesis of $\left[\operatorname{Pt}\left(L^{3}\right)\right]$}

The synthesis of $\left[\mathrm{Pt}\left(\mathrm{L}^{3}\right)\right]$ was carried out in an identical manner to $\left[\mathrm{Pt}\left(\mathrm{L}^{1}\right)\right]$ starting from $\mathrm{K}_{2} \mathrm{PtCl}_{4}(13 \mathrm{mg}, 0.031 \mathrm{mmol})$ and $\mathrm{L}^{3}(11 \mathrm{mg}, 0.031 \mathrm{mmol})$. Yellow solid.(13 mg, 76.5\%) $\mathrm{IR}\left(\mathrm{KBr}\right.$, pellet)v/cm $\mathrm{cm}^{-1}: 1620,1125,560,462$. Anal. Calc. for $\mathrm{C}_{20} \mathrm{H}_{20} \mathrm{~N}_{2} \mathrm{O}_{4} \mathrm{Pt}$ (547.46): $\mathrm{C}$, 43.88; H, 3.68; N, 5.21. Found: C, 43.81; H, 3.52; N, 5.37.

\section{Synthesis of $\left[\operatorname{Pt}\left(L^{4}\right)\right]$}

The synthesis of $\left[\mathrm{Pt}\left(\mathrm{L}^{4}\right)\right]$ was carried out in an identical manner to $\left[\mathrm{Pt}\left(\mathrm{L}^{1}\right)\right]$ starting from $\mathrm{K}_{2} \mathrm{PtCl}_{4}(15 \mathrm{mg}, 0.036 \mathrm{mmol})$ and $\mathrm{L}^{4}(13 \mathrm{mg}, 0.031 \mathrm{mmol})$. Yellow solid (14 mg, 73.4\%). IR(KBr, pellet)v/cm ${ }^{-1}: 1619,1121,527,474$. Anal. Calc. for $\mathrm{C}_{29} \mathrm{H}_{25} \mathrm{~N}_{2} \mathrm{O}_{2} \mathrm{Pt}(628.60)$ : C, 55.41; H, 4.01; N, 4.46. Found: C, 55.24; H, 4.13; N, 4.37.

\section{Synthesis of $\left[\operatorname{Pt}\left(L^{5}\right)\right]$}

The synthesis of $\left[\mathrm{Pt}\left(\mathrm{L}^{5}\right)\right]$ was carried out in an identical manner to $\left[\mathrm{Pt}\left(\mathrm{L}^{1}\right)\right]$ starting from $\mathrm{K}_{2} \mathrm{PtCl}_{4}(12 \mathrm{mg}, 0.036 \mathrm{mmol})$ and $\mathrm{L}^{5}(18 \mathrm{mg}, 0.036 \mathrm{mmol})$. Yellow solid $(16 \mathrm{mg}, 64 \%)$. $\mathrm{IR}\left(\mathrm{KBr}\right.$, pellet)v/cm $\mathrm{cm}^{-1}: 1619,1121,534,484$. Anal. Calc. for $\mathrm{C}_{34} \mathrm{H}_{33} \mathrm{~N}_{2} \mathrm{O}_{2} \mathrm{Pt}$ (696.72): $\mathrm{C}$, 58.61; H, 4.77; N, 4.02. Found: C, 58.44; H, 4.53; N, 4.21.

\section{DNA interaction procedure}

Three replicate measurements were carried out for each electrochemical experiment. All data were obtained at room temperature.

Interaction of DNA with metal complexes: Metal complex in the concentration level of $100 \mu \mathrm{g} / \mathrm{mL}$ (unless otherwise indicated) was added to supporting electrolyte containing 100 $\mu \mathrm{g} / \mathrm{mL}$ DNA. A pencil graphite electrode was first pre-treated as described above and subsequently immersed into the mixture solution. The accumulation of the mixture was performed for $3 \mathrm{~min}$ while holding the potential at $+0.50 \mathrm{~V}$ under stirred conditions. The electrode was then washed with a clean supporting electrolyte for $8 \mathrm{~s}$.

Signal transduction: The oxidation signals of guanine and adenine were measured by using differential pulse voltammetry with the following parameters: amplitude $50 \mathrm{mV}$, step potential $8 \mathrm{mV}$, pulse width $0.06 \mathrm{~s}$, pulse period $0.2 \mathrm{~s}$, setting time $4 \mathrm{~s}$, between +0.45 and $+1.40 \mathrm{~V}$ in a fresh supporting electrolyte. Successive measurements were carried out by repeating the above assay protocol. 


\section{Results and Discussion}

\section{Chemistry}

The symmetric schiff bases ligands $L^{1}-L^{5}$ and their complexes were prepared as shown in Scheme 1. The platinum complexes $\left[\mathrm{Pt}\left(\mathrm{L}^{1}\right)\right] \sim\left[\mathrm{Pt}\left(\mathrm{L}^{5}\right)\right]$ have been prepared by the reaction of $\mathrm{K}_{2} \mathrm{PtCl}_{4}$ with symmetric schiff bases in a mixture of $\mathrm{CH}_{3} \mathrm{OH} / \mathrm{H}_{2} \mathrm{O}$. Unfortunately, there is no clear NMR data of the complex due to the low intensity of the signals.

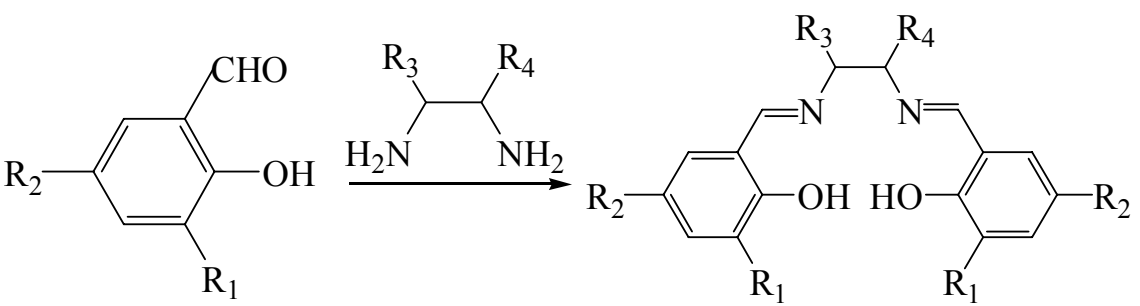

$\mathrm{a}_{1}: \mathrm{R}_{1}=$ tert-butyl $\mathrm{R}_{2}=\mathrm{CH}_{3}$

$\mathrm{L}^{1}: \mathrm{R}_{1}=\mathrm{R}_{2}=\mathrm{R}_{3}=\mathrm{R}_{4}=\mathrm{H}$

$\mathrm{L}^{4}: \mathrm{R}_{1}=\mathrm{R}_{2}=\mathrm{H} \quad \mathrm{R}_{3}=\mathrm{R}_{4}=\mathrm{ph}$

$\mathrm{L}^{5}: \mathrm{R}_{1}=$ tert-butyl $\mathrm{R}_{2}=\mathrm{CH}_{3} \quad \mathrm{R}_{3}=\mathrm{R}_{4}=\mathrm{ph}$<smiles></smiles><smiles>[R5]c1ccc(O)c(C=NC2CCCCC2/N=C/c2cc([R5])ccc2O)c1</smiles>

$\mathrm{a}_{2}: \mathrm{R}_{5}=\mathrm{OH}$

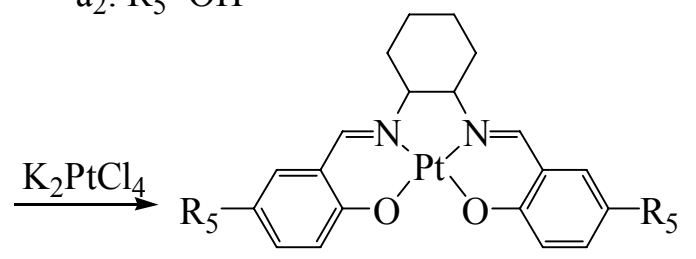

$\mathrm{L}^{2}: \mathrm{R}_{5}=\mathrm{H}$

$\mathrm{L}^{3}: \mathrm{R}_{5}=\mathrm{OH}$

Scheme 1. Synthesis of $\mathrm{L}^{1}-\mathrm{L}^{5}$ and Pt complexes.

Main IR absorptions of ligands and complexes were shown in Table 1. Comparison of the IR spectra of the free ligands with that of their $\mathrm{Pt}(\mathrm{II})$ complexes, the $(\mathrm{CH}=\mathrm{N})_{\text {imine }}$ stretching frequencies were found in free ligand at 1632, 1629,1630,1623 and $1625 \mathrm{~cm}^{-1}$, while in complexes shifted to low wavenumbers at 1625, 1620,1620,1619 and $1619 \mathrm{~cm}^{-1}$. On the other hand, in the spectra of a metal complexes, the bands for the phenolic group (C-O) 
shifted from $1149,1148,1157,1151$ and $1165 \mathrm{~cm}^{-1}$ to $1129,1124,1125,1121$ and $1121 \mathrm{~cm}^{-1}$, comparing to the free ligands. New bands appeared at about $460-485$ and $530-565 \mathrm{~cm}^{-1}$ and were may assigned to $v_{\mathrm{Pt}-\mathrm{O}}$ and $v_{\mathrm{Pt}-\mathrm{N}}$, respectively. All of these indicated that nitrogen atoms of the imine groups and oxygen atoms of the phenolic groups are coordinated to the metal ion. Elemental analysis also confirms the named stoichiometries of all the complexes.

Table 1. Main IR absorptions of ligands and complexes $\left(\mathrm{cm}^{-1}\right)$.

\begin{tabular}{ccccc}
\hline & $v(\mathrm{C}=\mathrm{N})$ & $v(\mathrm{C}-\mathrm{O})$ & $v(\mathrm{Pt}-\mathrm{N})$ & $v(\mathrm{Pt}-\mathrm{O})$ \\
\hline $\mathrm{L}^{1}$ & 1632 & 1149 & & \\
$\mathrm{~L}^{2}$ & 1629 & 1148 & & \\
$\mathrm{~L}^{3}$ & 1630 & 1157 & & \\
$\mathrm{~L}^{4}$ & 1623 & 1151 & & \\
$\mathrm{~L}^{5}$ & 1625 & 1165 & & \\
$\operatorname{Pt}\left(\mathrm{L}^{1}\right)$ & 1625 & 1129 & 563 & 485 \\
$\operatorname{Pt}\left(\mathrm{L}^{2}\right)$ & 1620 & 1124 & 566 & 468 \\
$\operatorname{Pt}\left(\mathrm{L}^{3}\right)$ & 1620 & 1125 & 560 & 462 \\
$\operatorname{Pt}\left(\mathrm{L}^{4}\right)$ & 1619 & 1121 & 527 & 474 \\
$\operatorname{Pt}\left(\mathrm{L}^{5}\right)$ & 1619 & 1121 & 534 & 484 \\
\hline
\end{tabular}

\section{DNA interaction of the complexes}

The oxidation peaks of dsDNA are virtually absent in differential pulse voltammetry, on the contrary, the well-developed voltammetric signals of ssDNA can be readily obtained. The large difference in the oxidation signals of dsDNA and ssDNA was due to the distinctness of accessibility and flexibility of two kinds of DNA ${ }^{19}$. Denaturation of DNA is performed by thermal heat up to $100{ }^{\circ} \mathrm{C}$ for about $15 \mathrm{~min}$, following by quick cooling in an ice bath. The redox behavior of tested complexes was investigated by differential pulse voltammetry in $0.5 \mathrm{M}$ acetate buffer $\mathrm{pH}=4.6$ containing $20 \mathrm{mM} \mathrm{NaCl}$, Voltammograms, which were monitored in blank supporting electrolyte (transfer voltammetry), obtained before/after interaction between $100 \mu \mathrm{g} / \mathrm{mL}^{-1} \mathrm{Pt}$ (II) complex and $100 \mu \mathrm{g} / \mathrm{mL}^{-1}$ ssDNA were shown in Figure 1 5.

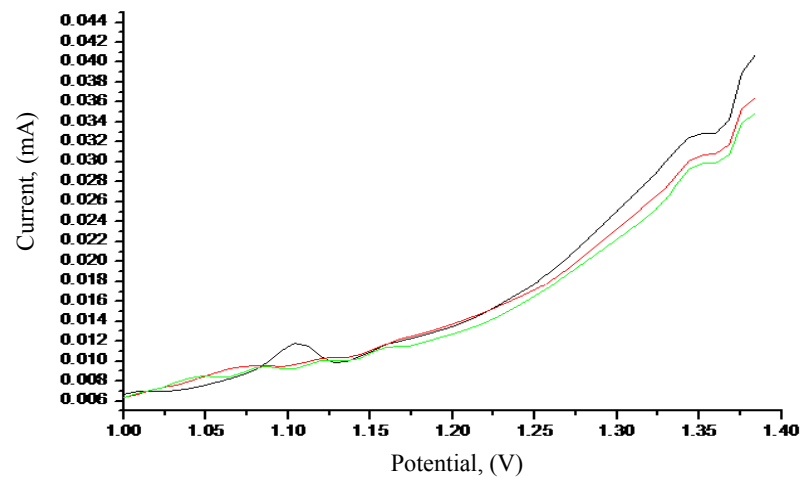

Figure 1. Interaction of ssDNA with $\left[\mathrm{Pt}\left(\mathrm{L}^{1}\right)\right] .(-)$ DNA blank. $(-)\left[\operatorname{Pt}\left(\mathrm{L}^{1}\right)\right]+$ DNA stirring after $0.5 \mathrm{~h} .(-)\left[\mathrm{Pt}\left(\mathrm{L}^{1}\right)\right]+$ DNA stirring after $12 \mathrm{~h}$. 


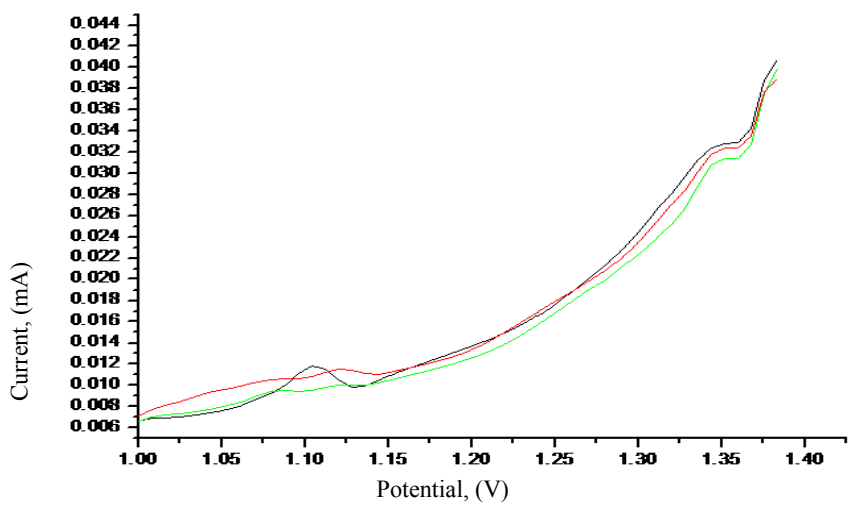

Figure 2. Interaction of ssDNA with $\left[\mathrm{Pt}\left(\mathrm{L}^{2}\right)\right]$. (-) DNA blank. $(-)\left[\mathrm{Pt}\left(\mathrm{L}^{2}\right)\right]+$ DNA stirring after $0.5 \mathrm{~h} .(-)\left[\mathrm{Pt}\left(\mathrm{L}^{2}\right)\right]+$ DNA stirring after $12 \mathrm{~h}$.

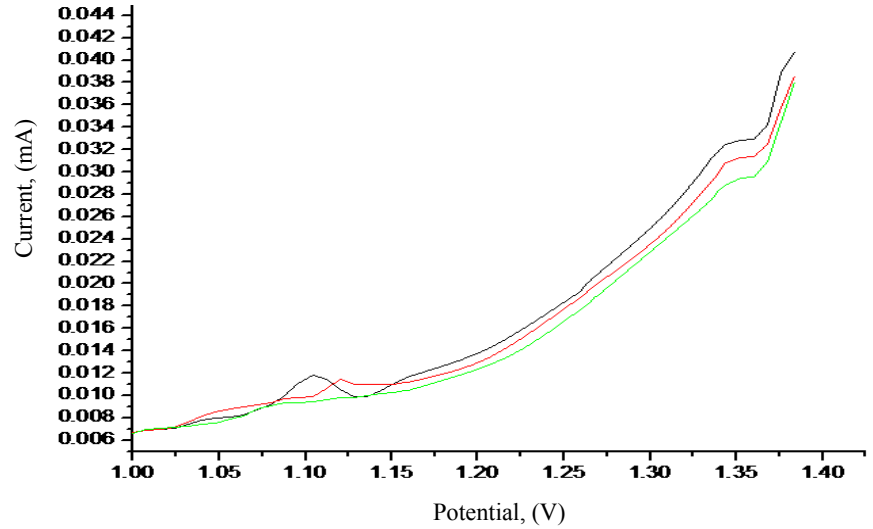

Figure 3. Interaction of ssDNA with $\left[\mathrm{Pt}\left(\mathrm{L}^{3}\right)\right]$. (-) DNA blank. $(-)\left[\mathrm{Pt}\left(\mathrm{L}^{3}\right)\right]+$ DNA stirring after $0.5 \mathrm{~h} .(-)\left[\mathrm{Pt}\left(\mathrm{L}^{3}\right)\right]+$ DNA stirring after $12 \mathrm{~h}$.

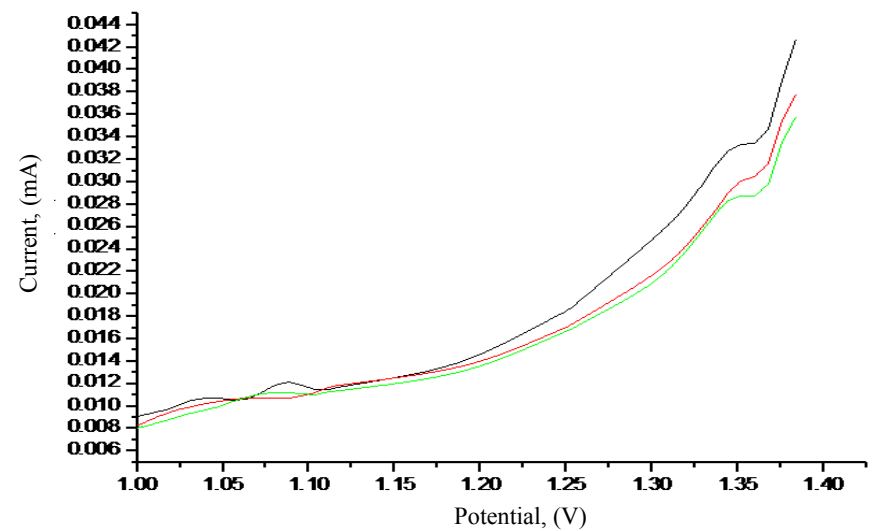

Figure 4. Interaction of ssDNA with $\left[\mathrm{Pt}\left(\mathrm{L}^{4}\right)\right] .(-)$ DNA blank. $(-)\left[\mathrm{Pt}\left(\mathrm{L}^{4}\right)\right]+$ DNA stirring after $0.5 \mathrm{~h} .(-)\left[\mathrm{Pt}\left(\mathrm{L}^{4}\right)\right]+$ DNA stirring after $12 \mathrm{~h}$. 


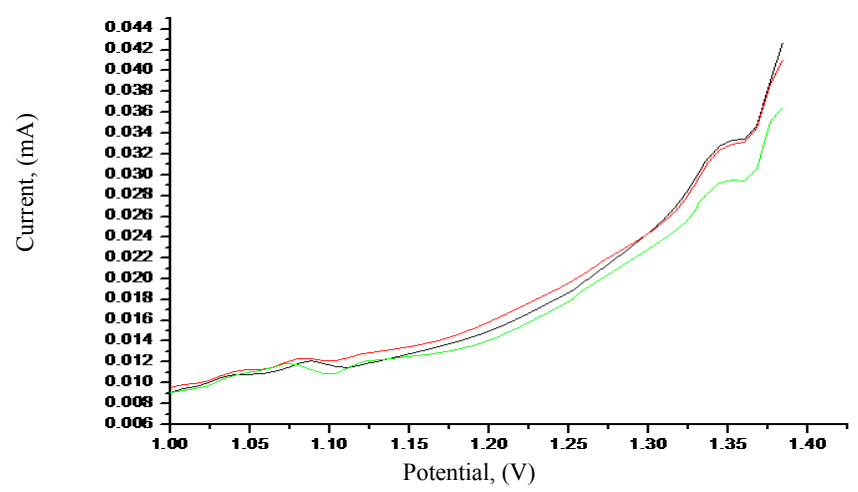

Figure 5. Interaction of ssDNA with $\left[\mathrm{Pt}\left(\mathrm{L}^{5}\right)\right] .(-)$ DNA blank. $(-)\left[\operatorname{Pt}\left(\mathrm{L}^{5}\right)\right]+$ DNA stirring after $0.5 \mathrm{~h} .(-)\left[\mathrm{Pt}\left(\mathrm{L}^{5}\right)\right]+$ DNA stirring after $12 \mathrm{~h}$.

Under the conditions of the experiment, the redox behavior of original ssDNA exhibited one positive peak at around $+1.10 \mathrm{~V}$ due to the oxidation of guanine residues, mean response $0.011 \pm 0.00025 \mathrm{~mA}(\mathrm{n}=3)$ and the second at around $+1.34 \mathrm{~V}$ due to the oxidation of adenine residues, mean response $0.032 \pm 0.00036 \mathrm{~mA}(\mathrm{n}=3)$. In the blank supporting electrolyte, we can see one clearly positive peak around $+1.50 \mathrm{~V}$, mean response $0.486 \mathrm{~mA}$, which is attributed to the oxidation of $\mathrm{Cl}^{-1}$. But unfortunately we could not see any positive peak singles about $\mathrm{Pt}(\mathrm{II})$ complexes.

Firstly, we reacted with five ligands and ssDNA in the room temperature in solution, and found no change of redox signal values of guanine and adenine residues. After the interaction of complexes and ssDNA in solution, redox signal values of guanine and adenine were shown in Table 2. Complex $\left[\mathrm{Pt}\left(\mathrm{L}^{1}\right)\right]$ had strong bonding with guanine and adenine residues after stirring $0.5 \mathrm{~h}$ at room temperature, the redox peaks of guanine and adenine residues decreased by 2.3 and $3.2 \mu \mathrm{A}$, from 0.0119 and $0.0333 \mathrm{~mA}$ to $0.0096 \mathrm{~mA}$ and $0.0301 \mathrm{~mA}$. When 1,2- ethylenediamine was replaced by the large ring planar steric 1,2-cyclohexanediamine $\left(\mathrm{L}^{2}\right)$, the bond formation of complex $\left[\mathrm{Pt}\left(\mathrm{L}^{2}\right)\right]$ with ssDNA significantly reduced, decreasing by 0.3 and $0.9 \mu \mathrm{A}$ after the stirring of $0.5 \mathrm{~h}$. 1,2-Cyclohexanediamine planar structure might hamper the interaction between Pt complex and ssDNA. In order to improve the water-solubility of complex, we introduced hydroxyl group in aromatic ring $\left(\mathrm{L}^{3}\right)$, expecting to enhance coordination of $\mathrm{Pt}$ complex $\left[\mathrm{Pt}\left(\mathrm{L}^{3}\right)\right]$ with ssDNA. However, we found the result had almost no change, the redox peaks of guanine and adenine residues only decreased by 0.9 and $2 \mu \mathrm{A}$ after $0.5 \mathrm{~h}$ stirring. To validate whether it was planar structure or not hindering coordination of complexes and DNA, we substituted 1,2-cyclohexanediamine to non-coplanar 1,2-diphenylethylenediamine $\left(\mathrm{L}^{4}\right)$. Compared to $\left[\mathrm{Pt}\left(\mathrm{L}^{2}\right)\right],\left[\mathrm{Pt}\left(\mathrm{L}^{4}\right)\right]$ had better interaction with ssDNA after stirring $0.5 \mathrm{~h}$, decreasing by 1.2 and $3.3 \mu \mathrm{A}$. On the other hand, we discussed the effect of interaction between aromatic substituents of complex and DNA. We joined tert-butyl and methyl to $o$ - and $p$ - of phenolic hydroxyl group respectively, synthesizing complex $\left[\mathrm{Pt}\left(\mathrm{L}^{5}\right)\right]$, and found that redox peak values of guanine and adenine had no change after $0.5 \mathrm{~h}$ stirring. Symmetrical tert-butyl on benzene ring effectively prevented attacking of $\mathrm{Pt}$ ion to ssDNA. We also observed the interactions between complexes and ssDNA after $12 \mathrm{~h}$ stirring, which were consistent to those after $0.5 \mathrm{~h}:\left[\mathrm{Pt}\left(\mathrm{L}^{1}\right)\right] \sim\left[\mathrm{Pt}\left(\mathrm{L}^{4}\right)\right]$ continued to interact with ssDNA. [Pt $\left.\left(\mathrm{L}^{5}\right)\right]$ almost had no coordination to guanine residues, but had better coordination to adenine residues. So we concluded that substituents on ligands can effectively influence the interaction between Pt complexes and DNA, bulky substituents on ligands can effectually embarrass the coordination of $\mathrm{Pt}$ ion to guanine and adenine residues. 
Table 2. Redox signal values of guanine and adenine (mA).

\begin{tabular}{ccccc}
\hline & \multicolumn{2}{c}{ Stirring after $0.5 \mathrm{~h}$} & \multicolumn{2}{c}{ Stirring after $12 \mathrm{~h}$} \\
& Guanie & Adenine & Guanie & Adenine \\
\hline DNA blank & 0.0119 & 0.0333 & & \\
$\operatorname{Pt}\left(\mathrm{L}^{1}\right)+$ DNA & 0.0096 & 0.0301 & 0.0092 & 0.0293 \\
$\operatorname{Pt}\left(\mathrm{L}^{2}\right)+$ DNA & 0.0116 & 0.0324 & 0.0096 & 0.0308 \\
$\operatorname{Pt}\left(\mathrm{L}^{3}\right)+$ DNA & 0.0110 & 0.0313 & 0.0095 & 0.0294 \\
$\operatorname{Pt}\left(\mathrm{L}^{4}\right)+$ DNA & 0.0107 & 0.0300 & 0.0108 & 0.0288 \\
$\operatorname{Pt}\left(\mathrm{L}^{5}\right)+$ DNA & 0.0120 & 0.0329 & 0.0118 & 0.0299 \\
\hline
\end{tabular}

\section{Conclusion}

Rare-earth platinum complexes have proved their effectiveness in tumor cells ${ }^{20}$. In this study five platinum complexes with symmetric tetradentate schiff base as ligands were synthesized and characterized. Compounds were tested for their DNA interaction ability with the fish sperm ssDNA using differential pulse voltammetry at pencil graphite electrode. The determined DNA binding levels for platinum complexes showed that $\left[\mathrm{Pt}\left(\mathrm{L}^{1}\right)\right]$ had the best interaction with DNA, substituents on ligands can effectively influence the interaction between Pt complexes and DNA, bulky substituents on ligands can effectually embarrass the coordination of Pt ion to guanine and adenine residues. However, these are preliminary observations and a more extensive study would be necessary in order to assert that the complexes act as cleavage agents.

\section{Acknowledgement}

This work was kindly supported by the fund from the Natural Science Foundation of Hebei Province (No. B2010000223) and Doctoral fundation of Hebei University (No. 2009-164).

\section{References}

1. Karia F D and Parsania P H, Asian J Chem., 1999, 11, 991-995.

2. Patel K H and Mehta A G, E-J Chem., 2006, 3, 103-109.

3. Singh K, Barwa M S and Tyagi P, Eur J Med Chem., 2006, 41, 1-9.

4. Panneerselvam P, Nair R R, Vijayalakshmi G, Subramanian E H and Sridhar S K, Eur J Med Chem., 2005, 40, 225-229.

5. Tovrog B S, Kitko D J and Drago R S, J Am Chem Soc., 1976, 98, 5144-5153.

6. Mladenova R, Ignatova M, Manolova N, Petrova T and Rashkov I, Eur Polym J., 2002, 38, 989-1000.

7. Hodnett E M and Dunn W J, J Med Chem., 1970, 13, 768-770.

8. Rosenberg B, Van Camp L and Krigas T, Nature., 1965, 205, 698-699.

9. Reedijk J, Chem Commun., 1996, 801-806. doi:10.1039/CC9960000801.

10. Reedijk J, Chem Rev., 1999, 99, 2499-510.

11. Kuo C Y, Wu M J, Lin C C, et al. Eur J Med Chem., 2010, 45, 55-62.

12. Cubo L, Pizarro A M, Quiroga A G, et al. J Inorg Biochem., 2010, 104, 909-918.

13. Kalayda G V, Fakih S, Bertram H, et al. J Inorg Biochem., 2006, 100, 1332-1338.

14. Farrer N J, Woods J A, Munk V P, et al. Chem Res Toxicol., 2010, 23, 413-421.

15. Coates C G, Jacquet L, McGarvey J J, Bell S E J, Alobaidi A H R and Kelly J M, J Am Chem Soc., 1997, 119, 7130-7136.

16. Gao E J, Yin H X, Zhu M C, Sun Y G, Gu X F, Wu Q and Ren L X, J Struct Chem., 2008, 49, 1048-1054.

17. Huang C Z, Li Y F, Hu X L and Li N B, Anal Chim Acta., 1999, 395, 187-197.

18. Renehan M F, et al. Journal of Molecular Catalysis A: Chemica., 2005, 231, 205-220.

19. Wu L L and Zhou J Z, Electrochimica Acta, 2000, 45, 2923-2927.

20. Abu-Surrah A S, Mini Rev Med Chem., 2007, 7, 203-211. 


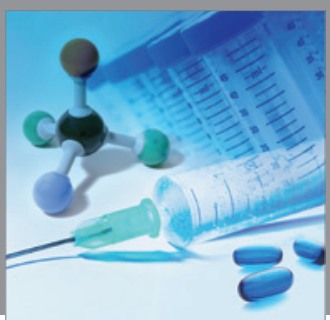

International Journal of

Medicinal Chemistry

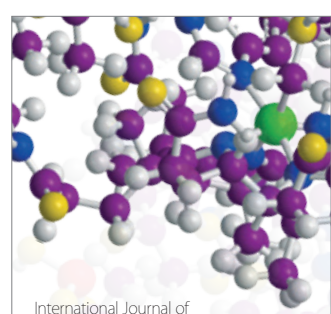

Carbohydrate Chemistry

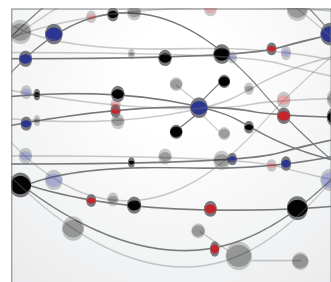

The Scientific World Journal
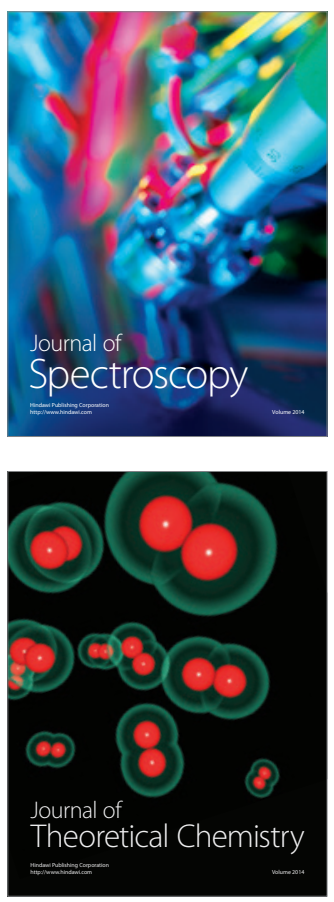
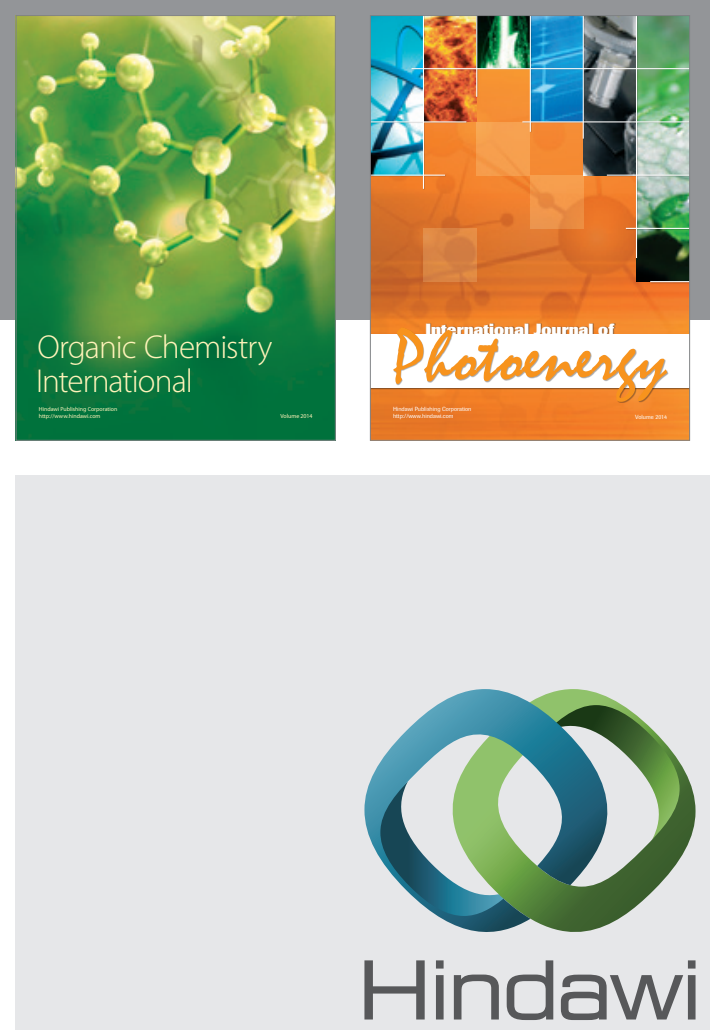

Submit your manuscripts at

http://www.hindawi.com
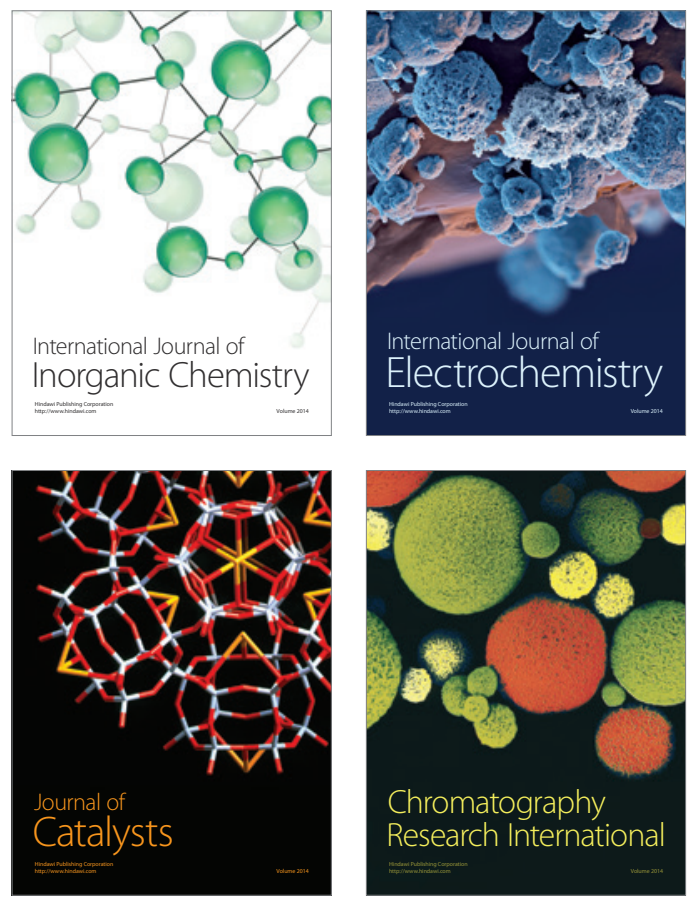
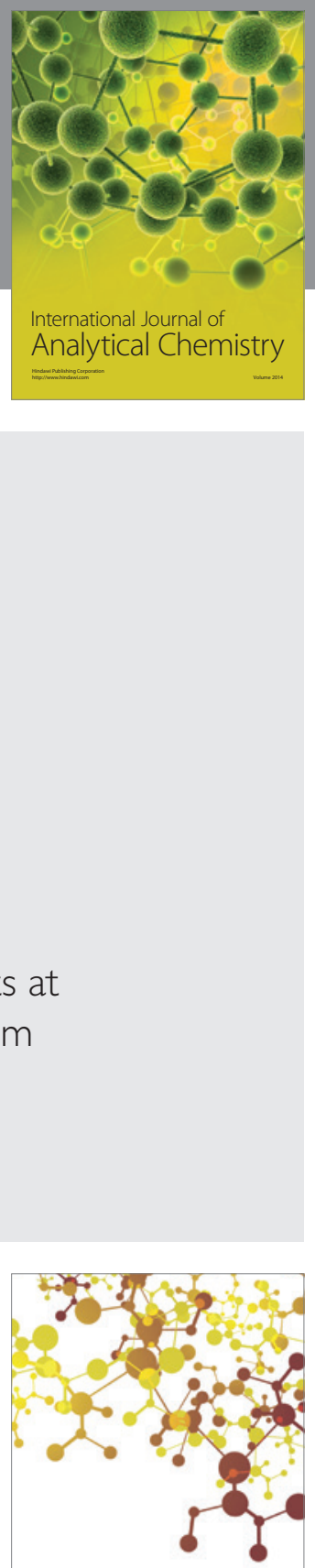

Journal of

Applied Chemistry
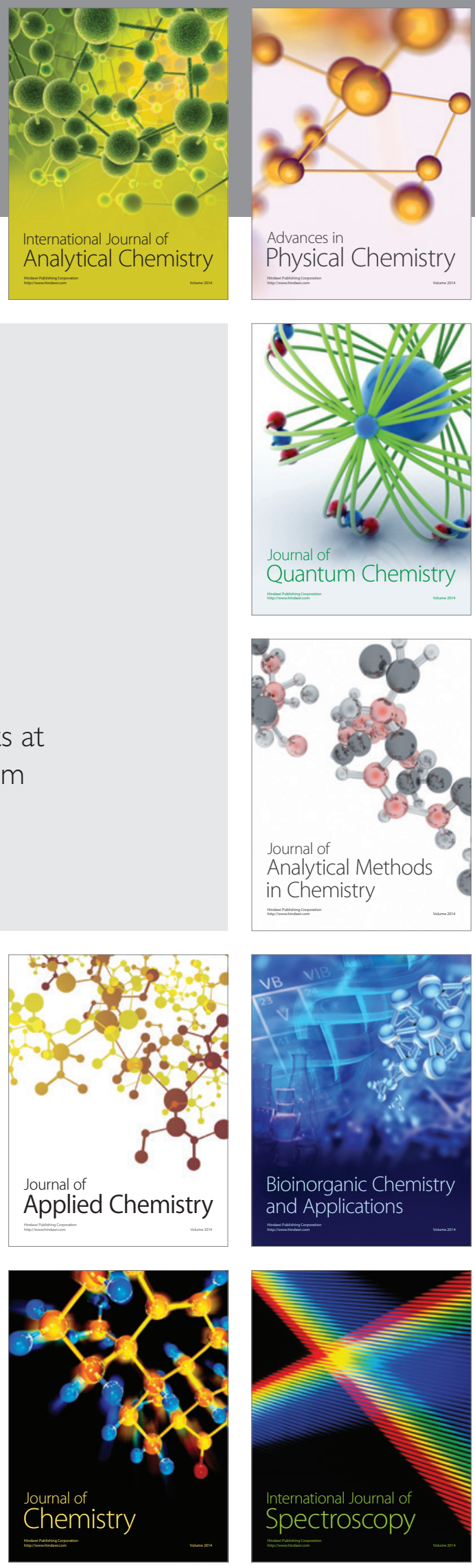